82

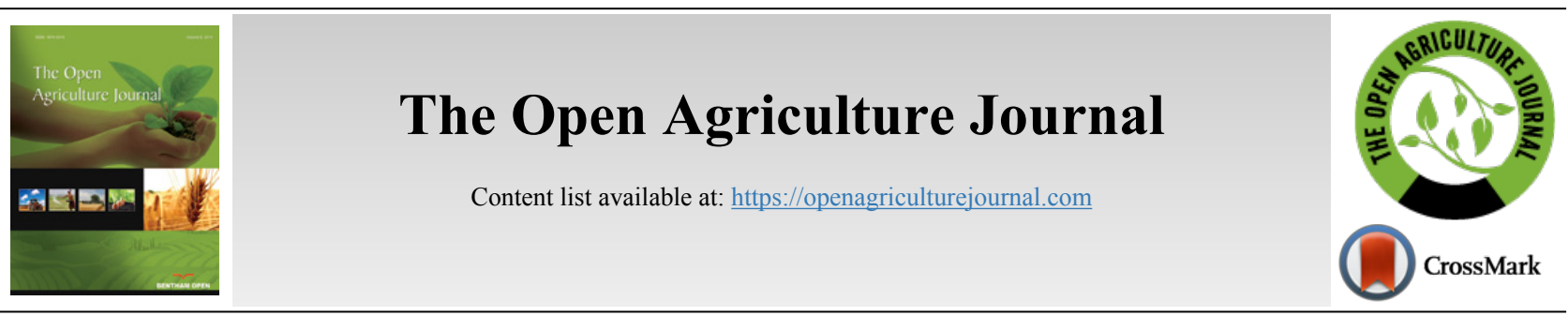

RESEARCH ARTICLE

\title{
Agriculture Development, Employment Generation and Poverty Reduction in West Africa
}

Romanus Osabohien*, Oluwatoyin Matthew, Obindah Gershon, Toun Ogunbiyi and Ebere Nwosu

Department of Economics and Development Studies, Covenant University, Ota, Nigeria

\begin{abstract}
:
Background:

The problem of poverty eradication has been limited to the Economic Community of West African States (ECOWAS) region, which accounts for more than $40 \%$ of the world's poor population. The majority of these people are rural farmers who depend solely on agriculture for livelihood. Agriculture in West Africa remains the largest means of employment in which more than $60 \%$ of the sub-region's active labour force is involved.

Objective:

This study examined the potentials of agriculture to generate employment for the people, thereby reducing the level of poverty in West Africa.

Methods:

The Generalized Method of Moments (GMM) econometric technique was employed in this study for the panel data covering the period of 17 years (2000 to 2016).

Results:

Results from the study showed that agriculture provides the opportunity for the poor to increase their earnings to escape the poverty trap, whether the poor can seize these agricultural opportunities depends on their human capital development.

Conclusion:

The study, therefore, concluded that effective policies (e.g. social protection) should be formulated in the agricultural development plans that will prioritize sustainable land and water management, access to markets, and the food security. To achieve this, the use of modern methods should be encouraged through farm incentives to boost agricultural production and increase farmer's income which is earned through the sale of agricultural commodities, and thus; in the long run, increase the revenue accruing to the government and reduce the rate of poverty.
\end{abstract}

Keywords: Agriculture, Development, Employment, GMM, Poverty, JEL Code, Q1, Q55, Q0.

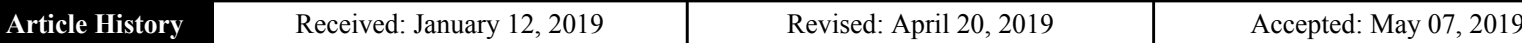

\section{INTRODUCTION}

Agriculture involves the cultivation of land for food and cash crops, fishing, forestry, hunting and other activities that relate to bringing out natural resources from the earth. Agriculture is the major activity in most of the West African countries, which constitutes about $60 \%$ of the total employment rate in the region in 2009 [1]. But employment in the agricultural sector has reduced to $54 \%$ in 2016 in the West African region due to the fact that young people are not moti-

* Address correspondence to this author at the Department of Economics and Development Studies, Covenant University, Ota, Nigeria; Tel: +2348064545217; Email: romanus.osabohien@covenantuniversity.edu.ng vated enough to participate in agriculture as occupation despite the fact that agricultural performance has been declining globally, the sector dominates the West African economies [2]. The agricultural sector in developing countries contributes significantly to the overall growth of their economies, and unarguably, agricultural development has special potentials for employment generation and poverty reduction [2]. Historically, scholars have not shown much concern about the role of agricultural development on employment generation and poverty reduction [3].

Reduction of agricultural contribution in national employment and Gross Domestic Product (GDP) is an inevitable 
consequence of the economic progress [3, 4]. This is largely due to higher income elasticity of demand for non-agricultural goods and services. This is because as their income grows, consumers increase their consumption of manufactured goods and services more than their consumption of food. Paradoxically, the process is usually accompanied by rising incomes and lowering the menace of poverty among rural dwellers that depend solely on agriculture as a means of livelihood [4]. This is due to the fact that in the rural areas, agriculture is recognized to be the main source of income and livelihoods, which implies that the growth in agricultural development has a direct impact on the welfare of the rural poor [5].

Over the years, there has been a long-standing interest on the relationship between agricultural development, employment generation and poverty reduction, as the number of people who are living in poverty and hunger continues to increase [6]. The issue of poverty is not limited to ECOWAS only, but it is also a global issue of concern. In 2016, about 815 million of the World population suffered hunger as a result of poverty, this was recognized to be the first increase in the rate of hunger since the food price crisis of 2006-2008 and is a substantial increase from the 777 million people who suffered from under-nourishment in 2015 [6].

To better situate the above argument, the West African agricultural sector generates more than $35 \%$ of GDP [6]. However, the practice of agriculture in this region has largely remained unattractive to the people, especially the youths for various reasons which include; low returns on time and input investments, limited access to land, low investments in infrastructure necessary for efficient value chains [7]. According to FAO [6], 1.3 billion people engage in various forms of agriculture around the world, $97 \%$ of these people are from developing countries; depending on the region, 30-50\% of household income in rural regions is generated directly through agriculture. Agriculture has great potential to provide an essential contribution to employment for the unemployed and reduce poverty among rural farmers because when people are employed they will have a source of livelihood and will be able to care for themselves and their dependents.

Export of agricultural commodities is the main source of ECOWAS external trade, in which about six billion Dollars (6bUSD) is generated, or approximately $16.3 \%$ of the tangible and intangible commodities are exported from the region [8]. The export potentials of the agricultural commodities generate a reasonable level of revenue that the governments use in paying for the importation of final products, equipment in terms of capital and intermediate goods for industrial use and services [9]. Estimated that the number of youths in West Africa that will be engaged in agriculture will reach 68.7 million by 2050 , which is more than the figure of $2011(31.8$ million), $16.2 \%$ of the estimated overall population and $40 \%$ of the estimated working-age population. In addition, there is also a disparity in the number of males and females engaged in agriculture in West Africa. In 2011, 54.7\% males and 55.2\% of females were engaged in agriculture, however, the figure dropped in 2016 to $53.5 \%$ for males and $53.8 \%$ for females. The estimated figures by 2050 are expected to be $50.45 \%$ and
$51.3 \%$ for males and females respectively [10]. It is seen from these figures that there are more females engaged in agricultural activities than males in the West African subregion.

Moreover, agriculture is an essential determinant in the quest for ending poverty at all levels, and achieving sustainable food security [7, 11]. A typical household in West Africa engages in subsistence farming with the use of local or crude implements like hoes and cutlasses which can only produce a limited level of agricultural output for family consumption [12]. Currently, about $80 \%$ of the ECOWAS population's food requirements are met by regional produce, but over the next few years, West African agriculture will have to meet a huge increase in demand produced by demographic growth. ECOWAS population presently stands at 290 million people and is projected to surpass 400 million by 2020 , and 500 million by 2030 [13].

Despite progress in reducing the prevalence of poverty (share of population living on less than $\$ 1.25$ a day) in low and middle-income countries, little progress has been made in reducing the number living on between $\$ 1.25$ and $\$ 2.00$ a day in ECOWAS [7]. Furthermore, poverty persists, with recent estimates showing that about 2 billion people may be considered poor [8]. However, it is relevant to bear in mind that human development in the form of health and education contributes to agricultural development, it was observed that the government of Ethiopia made significant efforts in terms of public investments (education and health) to speed up the growth of agriculture as a means of enhancing the poverty reduction agenda [5].

The health status of the people plays an important role in increasing agricultural production, and measures can be put in place to educate the farmers on the use of ICTs (modern implements) for efficient production [14]. It is also important to note that when individuals are fit that they can be involved in meaningful productive activities, which of course applies also to the practice of agriculture [15, 16]. In addition, education is equally important in bringing about growth in the agricultural sector. Education is regarded as a basic and obvious process by which skills, knowledge and attitude are acquired for the performance of socio-economic responsibilities, social integration, improving personal competence and seeking better opportunities. There is a need for the farmers to be educated either formally or informally to be able to use mechanized equipment to farm as this will help increase agricultural output $[17,18]$.

This study is structured into five sections which are; the introductory section, following this is section two which draws insight from relevant literature; section three comprises of the methodology employed and results; discussion of results and the summary of findings are presented in section four, while recommendations and conclusion are presented in section five.

\section{INSIGHTS FROM THE LITERATURE}

As stated in the introductory section, that over the years, limited issues have attracted scholars' attention as per the link between agricultural development, poverty reduction and employment generation in an economy. This has generated an 
enormous literature of both theoretical and empirical studies. Much literature focuses on the process of structural transformation of economies, from the least developed in which economic activity is based largely on agriculture, to high-income countries where industry and services sectors dominate the economy [4].

As revealed in the study of Cisse and, Mendy [19], the causes of poverty in ECOWAS include; poor governance, inequality in distribution, the high rate of unemployment, lack of economic diversification, low GDP per capita amongst others. The high unemployment rate, poor governance and income inequality causes an increase in the rate of social vices such as armed robbery, prostitution, kidnappings and drug trafficking in ECOWAS. Most of the countries in ECOWAS depend only on one sector for revenue generation and this accounts for why the GDP per capita is low in these countries [20]. Human capital is seen as a broad concept which identifies human characteristics that can be acquired through education and health and also increase income. It is commonly taken to include peoples' knowledge and skills acquired partly through education, but can also include their strength and vitality, which are dependent on their health and nutrition. The human capital theory thus focuses on health and education as inputs in economic production. The irony of it is that the agricultural sector provides food that helps to nourish the body for healthy living. When the people are in good health, they are able to contribute to aggregate output, and when output increases, poverty is reduced [18].

According to the literature, countries with a high level of human capital need twice as more growth as countries with a high level of human capital to meet the poverty target [21]. The largest number of the people who are living below the poverty line are from two main regions: 'Southern Asia and subSaharan Africa' and it is observed that two in five children aged five and below in these regions have the insufficient height for their age due to undernourishment [6].

Study of Diao et al [22] examined the effect of various channels of growth on the decrease in poverty and the overall growth rate in six low-income countries of Africa. The findings of their study revealed that industrial growth is less effective in reducing poverty than agricultural growth because high percentage of the population (about 70\%) live in rural areas. The agricultural sector is favourable as it allows greater employment opportunities for the poor. It was also noted that even though the industrial sector is important for boosting the economy, but it does not create sufficient employment opportunities for the poor and unskilled workers [22]. In addition, the study stated that there was little evidence to prove that African countries could launch a successful economic transformation without going through an agricultural revolution on a country-wide basis.

Callistus and Mulugeta, [23] examined the impact of social grants on poverty reduction at the household level in Ghana; they employed the usage of well-structured questionnaires, focus group discussions and in-depth interviews in their study. The study found out that the Livelihood Empowerment Against Poverty (LEAP) social grant has a positive impact on food consumption, frequency of utilization of health care facilities and the school enrolment rate for children aged 6-13years in beneficiary households. The study recommended that the government should increase the cash amount, pay transfers regularly, link beneficiaries to existing complimentary services in the district, recruit more staff and provide in-service training opportunities for them. In line with a study [23], another study [24] carried out an empirical study on the role of agriculture in the economic development of Nigeria. They used trend analysis in terms of historical and current perspectives of agricultural activities as well as various descriptive methods to analyze the development of agriculture and its relevance to the Nigerian economy. The study proved that an in-depth research on the development of the agricultural sector is essential for the progress of the country.

Furthermore, less emphasis is made in proffering solutions to the achievement of economic development through the tool of agriculture. An empirical investigation was carried out noting that the agricultural sector has significant potentials for the transformation of the African economy [25]. The study further acknowledged that most important public policies in West Africa have been tailored towards food security, the supply of agricultural raw materials needed by the manufacturing sector to provide adequate employment and income. The study recommended that credit should be provided to the farmers, extension services, price stabilization and making agriculture a priority. In the same context, [the relationship between rurality and poverty as well as the role they play in rural development and poverty reduction was also investigated [26].

It was argued that there was a historical misjudgment against the primary sector which served as a foundation for anti-agricultural bias in public policy until the late 1980s. This historical misjudgment, according to a study [26], is the use of crude implements to practice farming in the rural areas which the farmers are not willing to disabuse their minds. Arguably, it was concluded that the least developed countries still necessarily need agriculture as their starting point for rural development in comparison to the advanced countries. In a related development, the role of agriculture in the development of the Nigerian economy from 1970 to 2008 was examined [1]. Johansen co-integration technique was used for analyzing the data. The result from the study showed that there is no significant impact of the agricultural sector on the economic development in Nigeria. Therefore, the study recommended that research and technology would drive agricultural development and increase agricultural productivity and the government should establish an agricultural fund to finance and facilitate medium and large scale agricultural production which will, in turn, enhance employment, production for local consumption and for export.

In another study, the role of agriculture in the economic growth and poverty reduction in Tanzania from 1980 to 2014 was examined using descriptive analysis [27]. The study showed that an increase in population (household size in rural areas) and poor public services in rural areas exacerbated the poverty condition and accelerate shifting from agriculture to non-agricultural activities especially in the educated youth. The study recommended that more people should be encouraged to 
practice farming in the rural areas and soft loans should be provided to the farmers if the nation wants to continue pursuing a high level of achievement in the provision of arable land. In addition, there should be a favourable climate which will help increase food production thereby ensuring availability of supply of agricultural produce.

In the same context, the effect of agricultural productivity on poverty reduction in Africa is examined [28]. They used the dynamic panel data approach (to take care of both time series and cross-sectional data) and the System-GMM technique (used to solve the problem of endogeneity and omitted variable bias) for the period 1991-2015. The empirical result suggested that agricultural value added per worker contributes significantly to reducing poverty in Africa. The study recommended that the development programmes targeted at enhancing agricultural productivity should encompass strategies for accessing credit in order to boost the asset base of rural farmer for a large scale commercial production and appropriate macroeconomic policies and sound institutional framework needs to be put in place in order to boost provision of social services, equitable land and credit access. Furthermore, agricultural technology, productivity and poverty are examined using a case study of Madagascar [29]. The spatially explicit dataset was employed in this study to link agricultural performance and rural poverty in Madagascar. The study showed that agricultural production constitutes an important part of any strategy to reduce the high poverty and food insecurity rates currently prevalent in rural Madagascar.

It has been observed from past studies that African youths prefer 'white collar' jobs to get engaged in the agricultural sector. This assertion was buttressed in a study [7], using the descriptive study to examine youth migration, livelihood prospects and the demographic dividend in the rural northeast of South Africa. They found out that only $10 \%$ of male youths were employed in the agricultural sector in 2000 and this reduced to $3 \%$ in 2012. Similarly, the percentage of female youths employed in the agricultural sector witnessed a reduction from $11 \%$ in 2000 to $6 \%$ in 2012 . They observed that the remaining parts of the population in both years were employed in other sectors of the economy. The study recommended that for employment in agriculture to increase more youths should be engaged in it and this would help reduce unemployment and reduce poverty.

\section{METHODOLOGY}

As stated earlier, West Africa is made up of 254 million people in 15 low-income countries, all of which have low United Nations Human Development Indices [8]. In this region, agriculture accounts for $65 \%$ of employment and $35 \%$ of Gross Domestic Product (GDP), irrespective of this, the rate of poverty remains high in this region, especially in rural areas where most of the people live and depends solely on agriculture for subsistence [8]. This scenario forms the basis of this study which aims to explore the potentials of agriculture towards poverty reduction and employment generation in West Africa. The study engages panel data for the period for 17 years (2000-2016) for selected variables (Table 1).

The empirical model for this study is related closely to the studies $[28,30]$. It should be noted that a study [30] argued that agriculture has the potentials for generating employment and reduce poverty, this is done through the increasing level of the income of households who engages in agriculture as evidenced in the Turkish economy in 2013: The implicit form of the model is a specified equation (1)

$$
Y_{t}=f\left(A_{i}, S_{i}, X_{i}, W_{i}, Z_{i}\right)
$$

Where $\mathrm{A}_{\mathrm{it}}=$ Agriculture Development, $\mathrm{S}_{\mathrm{it}=}$ Employment; $\mathrm{X}_{\mathrm{it}}=$ Human Developmen ${ }_{\mathrm{t}}, \mathrm{W}_{\mathrm{it}}$ =Dependency Rate; $\mathrm{Z}_{\mathrm{it}}=$ Malthusian population Growth component. The explicit form of the model is formulated in equation (2)

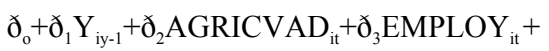

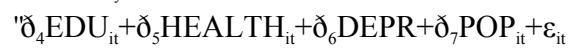

Where $Y_{i t}$ represents poverty (POV), AGRICVAD represents value added as a proxy for agricultural development [28]; EMPLOY represents employment proxied by agriculture employment; EDU represents Education; HEALTH represents health status. Education and Health were used as proxies for human capital development in this study; DEPR represents the dependency ratio; POP represents population growth rate as in Malthusian population growth model. ' $i$ ' represents entities

Table 1. Variables, definitions and source of data.

\begin{tabular}{|c|c|c|c|}
\hline Data & Identifier & Source & Definition and Measurement \\
\hline Poverty & POV & WDI & $\begin{array}{c}\text { Poverty was captured by Poverty headcount which is measured by the number of people living below } \\
\text { the poverty line (ratio at national poverty line \% of the total population) }\end{array}$ \\
\hline $\begin{array}{c}\text { Agriculture } \\
\text { Development }\end{array}$ & AGRIVAD & WDI & Agriculture development is proxied by agriculture, value added (\% of GDP) \\
\hline Employment & EMPLOY & \multirow{2}{*}{ WDI } & $\begin{array}{c}\text { Employment in this study was proxied by Employment in agriculture, the labor force in agriculture } \\
\text { which is the total number of people (male and female) who engages in the sector and it was measured } \\
\text { as \% of total employment (Dahiya, 2012) }\end{array}$ \\
\hline Human development & EDU & \multirow{2}{*}{ WDI } & Government expenditure on education, total (\% of government expenditure) \\
\cline { 2 - 3 } & HEALTH & Health expenditure, public (\% of government expenditure) \\
\hline Dependency Ratio & ADEPR & WDI & Age dependency ratio (\% of working-age population) \\
\hline Population & POP & WDI & Population refers to the total number of people living in a country. \\
\hline
\end{tabular}

Source: Authors' Compilation, 2018. Note: WDI means World Development Indicator 
(the fifteen West African countries) and ' $t$ ' represents time (period under review: 2000-2016) respectively; $\mathrm{Y}_{\mathrm{t}-1}$ represents the lagged dependent variable (to eliminate omitted variable bias and control for endogeneity). $ठ$ represents parameters and ' $\varepsilon$ ' represents the error term.

The main variables of interest in this study are agricultural development and employment, which aims to reduce poverty. The apriori expectation is that their coefficients should have negative signs. This implies that an increase in agricultural development and employment has a reduction in poverty, hence: $\partial 2, \partial_{3}<0$.

Also, due to the dynamic nature of the model (the inclusion of the lagged endogenous variable in the model), to ensure that estimates are Best, Linear, Unbiased and Efficient (BLUE), address the issue of endogeneity, omitted variable bias and reverse causality, the Generalized Method of Moments (GMM) econometric technique was employed [14]. The variable definition, source and measurement are explained in Table $\mathbf{1 .}$

\section{RESULTS AND DISCUSSION}

This sub-section of the study presents the estimated results and discussions. The starting point of the estimation is to determine the summary statistics of the variables. Table $\mathbf{2}$ presents the summary statistics of the variables. The results showed that the key variables (agricultural development and employment) have a statistically significant relationship with poverty. This supports the a priori expectation of the variables which suggests that agriculture development, employment, and other control variables like human capital development (education and health) together contribute to poverty reduction in West Africa. While population and dependency ratio showed a positive result with poverty. This means an increase in population and dependency ratio increases the incidence of poverty. This summary statistics of variables is presented in Table 2.

As stated earlier, this study engaged the Generalized Method of Moments (GMM) econometric technique to achieve its objectives. The advantage of the GMM technique is that its estimators are clearly noticed when the units of the dynamic panel model are relatively larger than the periods of study [31, 32]. However, the GMM estimator has overtime been found to have poor finite sample properties (bias) where the series are highly persistent [33]. In these circumstances, the lagged levels of the series are weakly correlated with subsequent first differences; thus, leading to weak instruments for the firstdifferenced equations [31,33]. demonstrated that the GMM approach - by including extra moment restrictions - permits lagged first differences to be used as instruments in the levels equations, and this corrects for any bias that would emerge using the GMM estimator. Care was taken in this study to ensure that GMM proliferation of instruments which may outfit endogenous variables are controlled, and it was observed that the model passed both the test for instrument validity (Sargan/Hansen the AR(2) and RA (2)) and the test for secondorder serial correlation [32]. The results from the GMM estimators are presented in Table $\mathbf{3}$.

\section{Table 2. Panel summary statistics of the variables.}

\begin{tabular}{|c|c|c|c|c|c|}
\hline Variable & Mean & Standard Deviation & Minimum & Maximum & Observations \\
\hline $\begin{array}{c}\text { Poverty } \\
\text { Overall }\end{array}$ & 50.44434 & 14.54202 & 7.1 & 82.1 & $\mathrm{~N}=212$ \\
\hline Between & & 15.3685 & 15.925 & 70.53333 & $\mathrm{n}=15$ \\
\hline Within & & 7.158134 & 19.83767 & 94.83767 & $\mathrm{~T}-\mathrm{bar}=14.1333$ \\
\hline Employment Overall & 54.52431 & 15.02823 & 20 & 83.3 & $\mathrm{~N}=255$ \\
\hline Between & & 14.72746 & 23.67647 & 79.48824 & $\mathrm{n}=15$ \\
\hline Within & & 4.755243 & 34.2949 & 68.08902 & $\mathrm{~T}=17$ \\
\hline Health Overall & 11.71185 & 7.986313 & 1.194823 & 49.39511 & $\mathrm{~N}=254$ \\
\hline Between & & 7.724399 & 2.817917 & 36.16978 & $\mathrm{n}=15$ \\
\hline Within & & 2.766334 & -2.178612 & 24.93719 & $\mathrm{~T}-\mathrm{bar}=16.9333$ \\
\hline Education overall & 21.92655 & 32.73212 & 1.84969 & 257.72 & $\mathrm{~N}=213$ \\
\hline Between & & 24.19463 & 2.577745 & 106.16 & $\mathrm{n}=15$ \\
\hline Within & & 21.44128 & -69.01345 & 173.4865 & $\mathrm{~T}-\mathrm{b}$ ar $=14.2$ \\
\hline $\begin{array}{c}\text { Agedpr } \\
\text { overall }\end{array}$ & 72.89389 & 35.75466 & 4.4003 & 130.3136 & $\mathrm{~N}=255$ \\
\hline Between & & 36.65392 & 4.520428 & 118.1501 & $\mathrm{n}=15$ \\
\hline Within & & 4.417726 & 55.66729 & 106.5944 & $\mathrm{~T}=17$ \\
\hline Agricvad Overall & 6.217979 & 35.75466 & 4.4003 & 130.3136 & $\mathrm{~N}=255$ \\
\hline Between & & 36.65392 & 4.520428 & 118.1501 & $\mathrm{n}=15$ \\
\hline Within & & 4.417726 & 55.66729 & 106.5944 & $\mathrm{~T}=17$ \\
\hline Population overall & 1.9007 & 3.5507 & 435079 & 1.8108 & $\mathrm{~N}=255$ \\
\hline Between & & 3.6307 & 490155.5 & $1.48 \mathrm{e} 08$ & $\mathrm{n}=15$ \\
\hline Within & & 5306330 & -9567358 & 5.2307 & $\mathrm{~T}=17$ \\
\hline
\end{tabular}


Table 3. SGMM results (dependent variable: poverty).

\begin{tabular}{|c|c|c|}
\hline & $\begin{array}{c}\text { Column 1 } \\
\text { Lag (2 2) }\end{array}$ & $\begin{array}{c}\text { Column 2 } \\
\text { Lag (2 3) }\end{array}$ \\
\hline Poverty(-1) & $4.2227^{*}$ & 10.0594 \\
$(0.004)$ & $(0.654)$ \\
\hline Agriculture Value Added & $-0.479^{*}$ & $-0.1374^{* *}$ \\
& $(0.000)$ & $(0.040)$ \\
\hline Population & $-0.2628^{*}$ & $0.1993^{*}$ \\
& $(0.000)$ & $(0.001)$ \\
\hline Employment & $-0.2483^{*}$ & $-0.593^{*}$ \\
& $(0.000)$ & $(0.001)$ \\
\hline Health & $0.02236^{* * *}$ & -0.3765 \\
& $(0.052)$ & $(0.064)$ \\
\hline Education & -0.2422 & $-0.3303^{* * *}$ \\
& $(0.400)$ & $(0.071)$ \\
\hline Dependency Ratio & $0.1317^{* *}$ & $0.0963^{*}$ \\
& $(0.014)$ & $(0.001)$ \\
\hline Constant & $30.99315^{*}$ & 1.630 \\
& $(0.000)$ & $(0.926)$ \\
\hline AR (1)Pr & 0.050 & 1.02 \\
\hline AR (2) & 0.096 & 3.65 \\
\hline Sargan Test & 0.10 & 4.4 \\
\hline Prob> F & $(0.000)$ & $(0.236)$ \\
\hline Number of Instruments & 8 & 10 \\
\hline Number of Groups & 15 & 15 \\
\hline
\end{tabular}

Source: Authors' Computation, 2018 using STATA 12. Note: The values in the parenthesis ' () ' are the probability values **and *** denotes that the coefficients are significant at $5 \%, 1 \%$, and respectively.

The Economic Community of West African States (ECOWAS) embarked on agriculture and rural development frameworks to strengthen the agricultural sector for productivity and employment generation towards poverty reduction in West Africa [8]. This project has led to the development of agricultural research priorities for some of the countries in West Africa such as; Ghana, Mali and Senegal as well as implementing the project at local levels. The project implementation at the national level is as a result of the national coordinating units at the Ministry of Food and Agriculture in Ghana, the Agriculture Services and Producer Organizations Support Programme in Mali, and the Agriculture Services and Producer Organizations in Senegal.

Agricultural development remains one of the major weapons for generating employment and reduction of poverty in West Africa. This is confirmed from the result obtained; from the result, improvement in agricultural development has the potential of reducing poverty by approximately $47.90 \%$ and 13.74\% (Table 3, column 1 and column 2 at lag 22 and lag 3 2) respectively. Similarly, employment is also a significant factor for poverty reduction in West Africa as was observed from the GMM result (Table 3; column 1 and 2; lags 22 and 3 2 ) that $1 \%$ increase in the level of employment approximately reduces poverty by $24.83 \%$ and $59.31 \%$. Human development (education and health) is also needed for poverty reduction and employment generation in West Africa.

In this study, it was observed that education also plays a significant role in reducing poverty, especially among rural dwellers that depend mainly on agriculture for survival. This is based on the fact that when people are educated, their income streams tend to increase and hence poverty reduces. Poverty will be reduced by $24.22 \%$ and $33.03 \%$ when people are educated (Table 3), likewise health, as health contributes $22.36 \%$ and $37.65 \%$ reduction on poverty. This study confirms the Malthusian theory of population where it was argued that population grows exponentially (in geometric progression) in developing countries, while food production grows arithmetically doubling with each cycle, in this wise, while food production is likely to increase in a series of twenty-five year intervals in the arithmetic progression, population is capable of increasing in geometric progression. This situation of arithmetic food growth with simultaneous geometric human population growth predicted a future with poverty.

However, the results from this study support the findings of previous studies that were carried out in exploring the potentials of agriculture in generating employment and reducing poverty $[32,34]$. The study of Osabohien et al. [35, 36] posited that though the agricultural sector dominates the African economy in terms of the labor force by employing two third of the poor located in the rural areas, the production capacity of the sector remains low. This calls for the need to develop the sector through effective programmes such as insurance against shocks and risk, provision of 'soft' loans with little interest rates to the farmers coupled with the provision of agricultural credits such as fertilizers. This will invariably get more people interested in agriculture and provide employment for more people both in the rural and urban areas and in turn poverty reduction [37].

Unfortunately, in spite of the potentials of agriculture in generating employment and reducing poverty in West Africa, the sector has been neglected because of the following reasons; among others not providing the necessary support needed in the agricultural sector. The study also finds that employment in agriculture is significant at $1 \%$ level and is negatively related to poverty, that is, the higher the rate of employment in agriculture, the lower the rate of poverty. However, this supports the theoretical underpinning that a higher level of employment in agriculture should help reduce the rate of poverty. The reason for this result in the ECOWAS countries is closely linked to the fact that the people engaged in agriculture are more in the rural communities and the majority of them still use crude implements with low productivity as the attendant outcome.

\section{SUMMARY AND CONCLUSION}

This study was motivated by the fact that agriculture remains one of the major keys for generating employment and poverty reduction, especially in West Africa which accounts for more than $40 \%$ of the World's poverty and poverty rates are higher among rural households that are farmers and uneducated [6]. This study focused on the ECOWAS region which is made of fifteen (15) member countries; Benin, Burkina Faso, Cape Verde, Cote d'Ivoire, Gambia, Ghana, Guinea, Guinea-Bissau, Liberia, Mali, Niger, Nigeria, Senegal, Sierra Leone, and Togo. The study makes use of secondary data sourced from the World Bank's World- Development Indicators for the period 2000-2016 and engages the generalized method of moments econometric technique.

An overview of the results showed that West African low 
agricultural productivity has led to increasing food imports and the loss of competitiveness for domestic producers. Agricultural development in the form of research funding has been low, but the adoption of proposed technologies has been even worse, at just $10 \%$ in 2007. The West Africa Agricultural Productivity Program (WAAPP) works to enhance agricultural development such as research and extension of agricultural technologies in Ghana, Mali and Senegal as well as other West African countries, focusing on the top agricultural priorities of each country.

In order to develop agriculture effectively, West Africa and other sub-Saharan Africa countries, have formulated agricultural development plans that prioritize sustainable land and water management, access to markets, and the reduction of hunger. Nevertheless, agricultural productivity has been declining in the West Africa. Average worldwide cereal yields $(2,676 \mathrm{~kg} / \mathrm{ha})$ more than doubled Africa's $(1,069 \mathrm{~kg} / \mathrm{ha})$ from 1994-2003, this demands ECOWAS competitiveness as food imports increased. Spending on agricultural research and extension in Africa, especially ECOWAS regional research, remains low, and linkages between research, extension, farmers, and agribusiness are weak, to the extent that in 2007 farmers adopted less than $10 \%$ of proposed technologies.

This study examined the nexus of agricultural development, employment in agriculture and poverty reduction in West Africa and based on the findings, the study recommends that; first, the government of these ECOWAS countries should put in place measures to educate and enlighten the farmers on the need to practice mechanised farming which will help reduce the stress they undergo with the use of crude implements like cutlasses and hoes which yield little returns. The use of modern implements will also help increase agricultural production and increase farmers income which is earned through the sale of agricultural commodities, and thus, in the long-run, this will, in turn, increase the revenue accruing to the government and reduce the rate of poverty.

\section{ETHICS APPROVAL AND CONSENT TO PARTI- CIPATE}

Not applicable.

\section{HUMAN AND ANIMAL RIGHTS}

No animals/humans were used for studies that are the basis of this research.

\section{CONSENT FOR PUBLICATION}

Not applicable.

\section{AVAILABILITY OF DATA AND MATERIALS}

Not applicable.

\section{FUNDING}

None.

\section{CONFLICT OF INTEREST}

The authors declare no conflict of interest, financial or otherwise.

\section{ACKNOWLEDGEMENTS}

Declared none.

\section{REFERENCES}

[1] Matthew AO, Adegboye FB. Agricultural sector and Economic Development: The Nigerian Experience. J Manage Enterprise Develop 2010; 7(2): 1117-377.

[2] Clunies-Ross A, Forsyth D, Huq M. Development Economics. $1^{\text {st }}$ ed. Glasgow, UK: Mc-Graw Hill Education 2009; p. 446.

[3] Byerlee D. de Janvry, A, E. Sadoulet Agriculture for Development: Toward a NewParadigm. Annu Rev Resour Econ 2009; 1(1): 15-35. [http://dx.doi.org/10.1146/annurev.resource.050708.144239]

[4] Cervantes-Godoy D, Dewbre J. Economic Importance of Agriculture for Poverty Reduction. OECD Food, Agriculture and Fisheries Working Papers 2010; 23.

[5] Abro ZA, Alemu BA, Hanjra MA. Policies for agricultural productivity growth andpoverty reduction in rural Ethiopia. World Dev 2014; 59: 461-74

[http://dx.doi.org/10.1016/j.worlddev.2014.01.033]

[6] Food and Agriculture Organisation-FAO. World Agriculture: Towards 2015/2030.FAOCorporate Document Repository 2017.

[7] Collinson MA, White MJ, Ginsburg C. Gomez-Olive, F. X. Youth migration, livelihood prospects and demographic dividend: A comparison of the census 2011 and agincourt health and surveillance system in the rural northeast of south africa. African Population Studies 2016; 30(2): 2629-39.

[PMID: 28663669]

[8] International Monetary Fund and World Bank. Global Monitoring Report 2014/2015: Ending Poverty and Sharing Prosperity. Washington, DC: International Monetary Fund 2015.

[9] UNDESA-United Nations Department of Economic and Social Development Affair. The Great Green Technological Transformation, World Economic and Social Survey 2011: E/2011/50/Rev. ST/ESA/333

[10] World Population Prospects: The 2015 Revision. New York: United Nations Publication 2015.

[11] Osabohien R, Osabuohien E, Urhie E. Food security, institutional framework and technology: Examining the nexus in nigeria using ARDL approach. Curr Nutr Food Sci 2018; 14(2): 154-63. [http://dx.doi.org/10.2174/1573401313666170525133853] [PMID: 29853816]

[12] Food and Agricultural Organization-FAO. The State of Food and Agriculture 2015 in Brief: Social Protection and Agriculture: Breaking the Cycle of Rural Poverty, 2015; 1-13.

[13] Regional Agricultural Policy for West Africa ECOWAP Working Paper Developed for the Paris Conference, 9th December 2008.

[14] Ejemeyovwi JO, Osabuohien ES, Osabohien R. ICT investments, human Capita development and institutions in ECOWAS. Int J Econ Bus Res 2018; 15(4): 463-74.

[http://dx.doi.org/10.1504/IJEBR.2018.092151]

[15] Matthew AO, Adegboye BF, Fasina FF. Public health expenditure and health Outcomes in nigeria. Int J Finance Econ 2015; 4(1): 45-56.

[16] Matthew O, Osabohien R, Fagbeminiyi F, Fasina A. Greenhouse gas emissions and health Outcomes in nigeria: Empirical insight from ARDL technique. Int J Energy Econ Policy 2018; 8(3): 43-50.

[17] Aigbokhan B, Imahe O, Ailemen MI, Imahe O, Ailemen MI. "Education expenditure and human capital development in nigeria: Any correlation so far? research paper. ambrose ali university ekpoma nigeria, 2007

[18] Matthew AO. Human Capital Investment and Economic Growth in Nigeria: The role of education and health, Manager, University of Bucharest. Faculty of Business and Administration 2011; 4: 266-77.

[19] Cisse A, Mendy P. Spatial Relationship between Floods and Poverty: The Case of Region of Dakar. Theor Econ Lett 2018; 83(3): 256-81. [http://dx.doi.org/10.4236/tel.2018.83019]

[20] Appleton S, Teal Human Capital F. Appleton, S. Teal F. Human Capital and Economic Development Economic Research Paper, 1998; No. 39

[21] Hammer L, Healey J, Naschold F. Will Growth Half Poverty by 2015? July. ODI Poverty Briefing 2000.

[22] Diao X, Hazell P, Thurlow J. The role of agriculture in African development. World Dev 2009; 38(10): 1375-83. [http://dx.doi.org/10.1016/j.worlddev.2009.06.011]

[23] Callistus A, Mulugeta D. Social grants and poverty reduction at the household level: Empirical evidence from ghana. J Dev Econ 2014; 
39(3): 293-330.

[24] Omorogiuwa O, Zivkovic J, Ademoh F. The role of agriculture in the economic development of nigeria. Eur Sci J 2014; 10(4): 133-47.

[25] Ogbalubi LN, Wokocha CC. Agricultural development and employment generation: The nigerian experience. J Agri Vet Sci 2013; 2(2): 60-9.

[http://dx.doi.org/10.9790/2380-0226069]

[26] Gustavo A, Kostas S. Rural development and poverty reduction: Is agriculture still the key? J Agri Develop Econo 2007; 4(1): 5-46.

[27] Eliamoni L, Fenggying N, Cheng F. The role of agriculture in the economic growthand poverty reduction in tanzania. J Econo Sustain Develop 2015; 6(14): 154-65.

[28] Ogundipe A, Ogunniyi A, Oduntan E, Olagunju K. Agricultural productivity, poverty reduction and inclusive growth in africa: Linkages and pathways. asian $\mathrm{j}$ agri extension Econ Sociol 2016; 18(1): 1-15.

[29] Bart M, Barrett C. Agricultural technology, productivity and poverty in Madagascar. World Dev 2008; 36(5): 797-822. [http://dx.doi.org/10.1016/j.worlddev.2007.05.004]

[30] Bayram A, Bayramoğl G. The Effect of Human Resource Practices on Burn-Out and the Mediating Role of Perceived Organizational Justice, International Conference on Economic Sciences and Business Administration, SpiruHaret University, 2014; 1(1) 37-45.

[31] Arellano M, Bover O. Another look at the instrumental variable estimation of error- 41 components models. J Econom 1995; 68(1): 29-51.

[http://dx.doi.org/10.1016/0304-4076(94)01642-D]

[32] Arellano M, Bond S. Some tests of specification for panel data: Monte carlo evidence and an application to employment equations. Rev Econ Stud 1991; 58(2): 277-97.

[http://dx.doi.org/10.2307/2297968]

[33] Blundell R, Bond S. GMM estimation with persistent panel data: An application to production functions. Econom Rev 2000; 19(3): 321-40. [http://dx.doi.org/10.1080/07474930008800475]

[34] Tersoo T. Agribusiness as a veritable tool for rural development in nigeria. Int Letters Soc Humanistic Sci 2013; 14: 26-36.

[http://dx.doi.org/10.18052/www.scipress.com/ILSHS.14.26]

[35] Osabohien R, Afolabi A, Godwin A. An econometric analysis of food security and agricultural credit facilities in Nigeria. Open Agric J 2018; 12: 227-39.

[http://dx.doi.org/10.2174/1874331501812010227]

[36] Osabohien R, Matthew O, Aderounmu B, Olawande T. Greenhouse gas emissions and crop production in West Africa: Examining the mitigating potential of social protection. Int J Energy Econom Policy 2019; 9(1): 57-66

[37] Osabohien R. Social protection programmes, agricultural production and youth employment nexus in nigeria: Analysis from LSMS-ISA. Int J Business Eco Manage 2018; 5(2): 45-55.

\section{(C) 2019 Osabohien et al.}

This is an open access article distributed under the terms of the Creative Commons Attribution 4.0 International Public License (CC-BY 4.0), a copy of which is available at: (https://creativecommons.org/licenses/by/4.0/legalcode). This license permits unrestricted use, distribution, and reproduction in any medium, provided the original author and source are credited. 